\title{
HUBUNGAN FAKTOR USIA DENGAN KELELAHAN PADA PASIEN SYSTEMIC LUPUS ERYTHEMATOSUS (SLE) DI KOMUNITAS LAMPUNG TAHUN 2019
}

\author{
Firhat Esfandiari 1, Sandhy Arya Pratama 2, Resati Nando Panonsih ${ }^{3}$, \\ Resia Evel Roselen ${ }^{4}$ \\ ${ }^{1}$ Departemen Penyakit Dalam Rumah Sakit Natar Medika \\ ${ }^{2}$ Departemen Histologi Fakultas Kedokteran Universitas Malahayati \\ ${ }^{3}$ Departemen Penyakit Kulit Kelamin Rumah Sakit Pertamina Bintang Amin \\ ${ }^{4}$ Program Studi Kedokteran Fakultas Kedokteran Universitas Malahayati
}

[email korespondensi: resiaevelroselen96@gmail.com]

\begin{abstract}
The Relationship Between Age And Fatigue In Systemic Lupus Erythematosus Patients In Lampung In 2019.

Systemic Lupus Erythematosus (SLE) occurs due to excessive production of antibodies in the body against the components of the cell nucleus, causing various clinical symptoms in organs. Fatigue is a major cause of morbidity in people with SLE. Based on data from the Lampung odapus community and the Hospital, every month there are around 5-6 people die from lupus from 150 members of the community. The relationship between age and fatigue in Systemic Lupus Erythematosus patients in Lampung in 2019. Quantitative research type, analytic design with cross sectional approach. The population in this study were 140 people with Systemic Lupus Erythematosus (SLE) in the Odapus Community in Lampung in 2019. Respondents who met the requirements and entered the inclusion criteria were 61 people. Data analysis techniques using the chi square test. Age frequency distribution in systemic lupus erytematosus (SLE) patients in the Odapus Community in Lampung (KOL) was mostly in the age category of 26-35 years (early adulthood) as many as 20 respondents (32.8\%), illustrating the level of fatigue mostly with fatigue category of 38 respondents $(62.3 \%)$. There is a relationship between age and fatigue in patients with Systemic Lupus Erythematosus (SLE) in the Odapus Community in Lampung (KOL) in 2019 ( $p$-valeu $0.019<a=0.05$ ). There is a relationship between age and fatigue in Systemic Lupus Erythematosus (SLE) patients in the Odapus Community in Lampung in 2019. It is recommended for health workers to educate and remind patients and their families to reduce and limit activities that can cause fatigue.
\end{abstract}

Keywords : Age, Fatigue, Systemic Lupus Erythematosus

\section{Abstrak: Hubungan Faktor Usia Dengan Kelelahan Pada Pasien Systemic Lupus Erythematosus (SLE) Di Lampung Tahun 2019.}

Systemic Lupus Erythematosus (SLE) terjadi karena produksi antibodi didalam tubuh berlebihan terhadap komponen inti sel, sehingga menyebabkan berbagai gejala klinis pada organ. Kelelahan merupakan penyebab utama morbiditas pada penderita SLE. Berdasarkan data dari komunitas odapus Lampung dan Rumah Sakit, setiap bulannya ada sekitar 5-6 orang meninggal karena penyakit lupus dari 150 anggota komunitas tersebut. Diketahui hubungan faktor usia dengan kelelahan pada pasien Systemic Lupus Erythematosus di Lampung Tahun 2019. Jenis penelitian kuantitatif, rancangan analitik dengan pendekatan cross sectional. Populasi dalam penelitian ini sebanyak 140 orang penderita Systemic Lupus Erythematosus (SLE) di Komunitas Odapus Lampung Tahun 2019. Responden yang memenuhi persyaratan dan masuk pada kriteria inklusi yaitu 61 orang. Teknik analisis data menggunakan uji chi square. Distribusi frekuensi usia pada pasien systemic lupus erytematosus (SLE) di Komunitas Odapus Lampung (KOL) sebagian besar dengan kategori usia 26-35 tahun (dewasa awal) sebanyak 20 responden 
$(32,8 \%)$, gambaran tingkat kelelahan sebagian besar dengan kategori kelelahan sebanyak 38 responden (62,3\%). Ada hubungan antara faktor usia dengan kelelahan pada pasien Systemic Lupus Erythematosus (SLE) di Komunitas Odapus Lampung (KOL) Tahun 2019 ( $p$-valeu 0,019< a = 0,05). Ada hubungan antara faktor usia dengan kelelahan pada pasien Systemic Lupus Erythematosus (SLE) di Komunitas Odapus Lampung (KOL) Tahun 2019. Disarankan bagi petugas kesehatan untuk mengedukasi dan mengingatkan pasien dan keluarga pasien untuk mengurangi dan membatasi aktivitas yang bisa menyebabkan kelelahan.

Kata Kunci : Usia, Kelelahan, Systemic Lupus Erythematosus

\section{PENDAHULUAN}

Lupus yaitu suatu penyakit yang disebabkan oleh penurunan sistem imun tubuh, yang secara langsung menyerang seluruh organ tubuh manusia mulai dari ujung kaki sampai ujung rambut. Gejala-gejala penyakit lupus pada setiap orang berbeda-beda, maka dari itu penyakit lupus di kenal dengan istilah "penyakit seribu wajah". Seseorang yang telah terdiagnosa penyakit lupus maka sistem imun didalam tubuhnya mengalami kekacauan yang menyebabkan zat antibodi dalam tubuh akan menyerang sistem tubuhnya sendiri dan tidak bisa berfungsi dengan semestinya untuk melindungi tubuh. (Salah satu penyakit autoimun kronis yaitu lupus yang biasanya dapat menyerang sistem organ yang berperan penting dalam tubuh, meliputi sistem organ ginjal, kulit, darah, otak dan beberapa system organ yang lainnya). (Djoerban,2015)

Systemic Lupus Erythematosus (SLE) terjadi karena produksi antibodi didalam tubuh berlebihan terhadap komponen inti sel, sehingga menyebabkan berbagai gejala klinis pada organ (Cleanthous et al, 2012). Systemic Lupus Erythematosus (SLE) memiliki perjalanan penyakit yang berbeda-beda dan mempunyai variasi gambaran klinis yang luas, meliputi keterlibatan kulit, sendi, jantung, paru, ginjal, susunan saraf pusat (SSP) dan sistem imun, oleh karena itu SLE memilik resiko kematian yang tinggi sehingga sangat memerlukan pengobatan yang cukup lama dan seumur hidup, untuk itu sangat diperlukan pengenalan dini serta penatalaksanaan yang tepat
(Kemenkes RI,2016). Penyakit systemic lupus erythematosus (SLE) belum diketahui penyebab secara pasti sampai saat ini, akan tetapi ada beberapa faktor yang diduga akan menjadi faktor resiko penyakit SLE yaitu regulasi sistem imun, hormon, genetik, lingkungan dan epigenetik. Lupus ialah penyakit auto imun kronis yang sampai saat ini belum diketahui secara tepat dan pasti penyebabnya, biasanya perempuan produktif dengan usia (15-44tahun), sangat rentan terkena SLE namun bisa juga menyerang laki-laki, kelompok anak-anak serta remaja.

Orang yang telah terdiagnosa mengalami penyakit lupus akan mengeluh berat badan turun, demam, lemah, anoreksia, malaise, gejala klinisnya akan lebih spesifik,lengkap dan akan cenderung melibatkan sistem organ lainnya jika pada penderita yang telah lanjut (berbulan-bulan serta bertahun-tahun). (Kemenkes RI,2017)

Systemic Lupus Erythematosus (SLE) memiliki data prevalensi yang berbeda-beda disetiap negara, data insidensi sebesar 0,9-3,1 per 100.000 populasi/tahun didapatkan pada suatu studi sistemik di Asia Pasifik. Prevalensi kasarnya sebesar 4,2-45,3 per 100.000 populasi. The Lupus Foundation of America memperkirakan kurang lebih sekitar 1,5 juta kasus yang terjadi di amerika dan lima juta kasus di dunia. Sekitar 16 ribu kasus baru lupus setiap tahunnya, di Indonesia, sendiri belum diketahui secara tepat dan pasti jumlah penderita penyakit lupus. Data prevalensi Systemic Lupus Erythematosus (SLE) di masyrakat 
berdasarkan survei yang dilakukan oleh Prof. Handono Kalim, dkk di Malang memperlihatkan angka sebanyak 0,5\% terhadap total populasi. (Kemenkes RI,2017).

Data prevalensi menurut penelitian oleh Ferucci, dkk (2014) penderita SLE di Amerika setelah memenuhi standarisasi umur adalah sebesar 177,7 per 100.000 populasi. Menurut data prevalensi dari Yayasan Lupus Indonesia (YLI) menunjukan peningkatan dari 12.700 orang pada tahun 2012 menjadi 13.300 orang per April 2013yang tersebar di wilayah Indonesia atau sekitar 4 per 100.000 populasi. Sedangkan di semua wilayah Indonesia belum terdapat data epidemiologi SLE. Di RSUD Dr.Pringadi didapatkan proporsi SLE sebesar 1 per 10.000 perawatan selama 3 tahun. Pada tahun 2002 data di RSUP Cipto Mangunkusomo (RSCM) Jakarta didapatkan proporsi SLE sebesar 1 per 1.000 kunjungan pasien di poliklinik Reumatologi Penyakit Dalam, dan di Rumah Sakit Hasan Sadikin Bandung mempunyai 291 penderita SLE atau 11 per 1.000 pasien yang berobat ke poliklinik Reumatologi Penyakit Dalam selama tahun 2010 (Perhimpunan Reumatologi Indonesia,2011)

Kelelahan merupakan penyebab utama morbiditas pada penderita SLE, serta penurunan kualitas hidup dan tingkat keparahan SLE dengan kriteria ringan sampai berat (Perhimpunan Reumatologi Indonesia,2011). Pada penderita SLE kelelahan ialah hal yang biasa yang sangat sering dirasakan. $53-80 \%$ penelitian menunjukan penderita SLE mengalami kelelahan sebagai suatu gejala utama mereka, pada $30-50 \%$ penderita SLE kelelahan adalah suatu gejala yang mengganggu fungsi fisik, social dan emosional serta yang paling melemahkan (Alvina 2007). Kelelahan merupakan faktor pencetus kekambuhan selain sinar matahari dan merupakan salah satu pencetus kondisi yang memperburuk gejala SLE. Pada penderita SLE system pertahanan tubuh melawan infeksi yang dihasilkan antibodi menyerang tubuhnya sendiri, pada keadaan orang normal sistem kekebalan tubuh akan berfungsi dengan semestinya untuk melindungi dan mengendalikam pertahanan tubuh melawan infeksi.

Berdasarkan survey yang peneliti lakukan di komunitas odapus Provinsi Lampung Tahun 2019 dengan melakukan wawancara terhadap ketua dan anggota komunitas odapus Lampung, saat ini sudah ada sebanyak 150 odapus yang bergabung dalam komunitas tersebut. Berdasarkan data dari komunitas odapus Lampung dan Rumah Sakit, setiap bulannya ada sekitar 5-6 orang meninggal karena penyakit lupus.

Penelitian mengenai hubungan faktor usia dengan kelelahan pada pasien systemic lupus erythematosus di Lampung masih sedikit, sehingga penulis tertarik untuk melakukan penelitian tentang hubungan faktor usia dengan kelelahan pada pasien systemic lupus erythematosus di Lampung Tahun 2019.

Menurut data prevalensi dari Yayasan Lupus Indonesia (YLI) menunjukan peningkatan dari 12.700 orang pada tahun 2012 menjadi 13.300 orang per April 2013yang tersebar di wilayah Indonesia atau sekitar 4 per 100.000 populasi. Sedangkan di semua wilayah Indonesia belum terdapat data epidemiologi SLE. Di RSUD Dr.Pringadi didapatkan proporsi SLE sebesar 1 per 10.000 perawatan selama 3 tahun. Pada tahun 2002 data di RSUP Cipto Mangunkusomo (RSCM) Jakarta didapatkan proporsi SLE sebesar 1 per 1.000 kunjungan pasien di poliklinik Reumatologi Penyakit Dalam, dan di Rumah Sakit Hasan Sadikin Bandung mempunyai 291 penderita SLE atau 11 per 1.000 pasien yang berobat ke poliklinik Reumatologi Penyakit Dalam selama tahun 2010 (Perhimpunan Reumatologi Indonesia,2011)

Kelelahan merupakan penyebab utama morbiditas pada penderita SLE, serta penurunan kualitas hidup dan tingkat keparahan SLE dengan kriteria ringan sampai berat (Perhimpunan Reumatologi Indonesia,2011). Pada penderita SLE kelelahan ialah hal yang biasa yang sangat sering dirasakan. 
$53-80 \%$ penelitian menunjukan penderita SLE mengalami kelelahan sebagai suatu gejala utama mereka, pada $30-50 \%$ penderita SLE kelelahan adalah suatu gejala yang mengganggu fungsi fisik, social dan emosional serta yang paling melemahkan (Alvina 2007). Kelelahan merupakan faktor pencetus kekambuhan selain sinar matahari dan merupakan salah satu pencetus kondisi yang memperburuk gejala SLE. Pada penderita SLE system pertahanan tubuh melawan infeksi yang dihasilkan antibodi menyerang tubuhnya sendiri, pada keadaan orang normal sistem kekebalan tubuh akan berfungsi dengan semestinya untuk melindungi dan mengendalikam pertahanan tubuh melawan infeksi.

Berdasarkan survey yang peneliti lakukan di komunitas odapus Provinsi Lampung Tahun 2019 dengan melakukan wawancara terhadap ketua dan anggota komunitas odapus Lampung, saat ini sudah ada sebanyak 150 odapus yang bergabung dalam komunitas tersebut. Berdasarkan data dari komunitas odapus Lampung dan Rumah Sakit, setiap bulannya ada sekitar 5-6 orang meninggal karena penyakit lupus.

Penelitian mengenai hubungan faktor usia dengan kelelahan pada pasien systemic lupus erythematosus di Lampung masih sedikit, sehingga penulis tertarik untuk melakukan penelitian tentang hubungan faktor usia dengan kelelahan pada pasien systemic lupus erythematosus di Lampung Tahun 2019.

\section{METODE}

Jenis penelitian yang digunakan adalah kuantitatif dengan desain penelitian analitik dan menggunakan pendekatan cross sectional. Populasi dalam penelitian ini sebanyak 140 orang penderita Systemic Lupus Erythematosus (SLE) di Komunitas Odapus Lampung Tahun 2019. Responden yang memenuhi persyaratan dan masuk pada kriteria inklusi yaitu 61 orang. Pengambilan data didapatkan dari wawancara langsung dengan responden atau menggunakan kuesioner Fatique Severity Scale (FSS). Analisis yang digunakan untuk pengujian adalah dengan menggunakan metode uji statistic Chi-Square.

HASIL

1. Karakteristik

Tabel. 1. Karakteristik Jenis Kelamin dan lama sakit pada pasien SLE

\begin{tabular}{lcc}
\hline Jenis Kelamin & Frekuensi & Persentase \\
\hline Laki-Laki & - & 0.0 \\
Perempuan & 61 & 100,0 \\
\hline \multicolumn{1}{c}{ Lama Sakit } & & \\
\hline -1 Tahun & 3 & 4,9 \\
1-5 Tahun & 39 & 63,9 \\
6-10 Tahun & 14 & 23,0 \\
$\geq 10$ Tahun & 5 & 8,2 \\
\hline
\end{tabular}

Berdasarkan Tabel 1. maka dapat diketahui bahwa jenis kelamin pada pasien systemic lupus erythematosus (SLE) di Komunitas Odapus Lampung (KOL) Tahun 2019 adalah perempuan sebanyak 61 responden (100\%), sebagian besar lama sakit pada pasien systemic lupus erythematosus (SLE) di Komunitas Odapus Lampung (KOL) Tahun 2019, 1-5 tahun sebanyak 39 responden $(63,9 \%)$.

\section{Analisis Univariat}

Tabel. 2. Karakteristik usia dan kelelahan pada pasien SLE

\begin{tabular}{lcc}
\hline \multicolumn{1}{c}{ Usia } & Frekuensi & Persentase \\
\hline 17-25 Tahun & 15 & 24,6 \\
26-35 Tahun & 20 & 32,8 \\
36-45 Tahun & 19 & 31,1 \\
46-55 Tahun & 7 & 11,5 \\
\hline \multicolumn{1}{c}{ Kelelahan } & & \\
\hline Tidak Kelelahan & 23 & 37,7 \\
$\leq 36$ & & 62,3 \\
Kelelahan $>36$ & 38 &
\end{tabular}

Berdasarkan Tabel 2. maka dapat diketahui bahwa usia pada pasien systemic lupus erythematosus (SLE) di Komunitas Odapus Lampung (KOL) Tahun 2019, sebagian besar adalah usia 26-35 tahun sebanyak 20 responden $(32,8 \%)$. tingkat kelelahan pada pasien systemic lupus 
erythematosus (SLE) di Komunitas Odapus Lampung (KOL) Tahun 2019 sebagian besar dengan kategori kelelahan sebanyak 38 responden $(62,3 \%)$, sedangkan dengan kategori tidak kelelahan sebanyak 23 responden $(37,7 \%)$.

Berdasarkan Tabel 3. diketahui bahwa 20 responden dengan kategori usia dewasa awal yang mengalami kelelahan 10 responden $(50,0 \%)$ dan yang tidak mengalami kelelahan 10 responden $(50,0 \%), 19$ responden dengan kategori usia dewasa akhir yang mengalami kelelahan 16 responden $(84,2 \%)$ dan yang tidak mengalami kelelahan 3 responden
$(15,8 \%), \quad 15$ responden dengan kategori remaja yang mengalami kelelahan 6 responden $(40,0 \%)$ dan yang tidak mengalami kelelahan 9 responden $(60,0 \%), 7$ responden dengan kategori lansia awal yang mengalami kelelahan 6 responden $(85,7 \%)$ dan yang tidak mengalami kelelahan 1 responden (14,3\%). Hasil uji statistik $p$-valeu $=0,019$ lebih kecil dari nilai alpha $(a=0,05)$, sehingga terdapat hubungan yang bermakna antara hubungan faktor usia dengan kelelahan pada pasien systemic lupus erythematosus (SLE) di Komunitas Odapus Lampung (KOL) Tahun 2019.

\section{Analisis Bivariat}

Table 3. Analisa hubungan faktor usia dengan kelelahan pada pasien systemic Iupus erythematosus (SLE) di Komunitas Odapus Lampung (KOL) Tahun 2019

\begin{tabular}{|c|c|c|c|c|c|c|c|}
\hline \multirow{3}{*}{ Usia } & \multicolumn{4}{|c|}{ Kelelahan } & \multirow{2}{*}{\multicolumn{2}{|c|}{ Total }} & \multirow{3}{*}{$p$-value } \\
\hline & \multicolumn{2}{|c|}{ Tidak Lelah } & \multicolumn{2}{|c|}{ Lelah } & & & \\
\hline & $\mathrm{N}$ & $\%$ & $\mathrm{~N}$ & $\%$ & $\mathrm{~N}$ & $\%$ & \\
\hline Remaja & 9 & 60,0 & 6 & 40,0 & 15 & 100,0 & \\
\hline Dewasa Awal & 10 & 50,0 & 10 & 50,0 & 20 & 100,0 & \\
\hline Dewasa Akhir & 3 & 15,8 & 16 & 84,2 & 19 & 100,0 & 0,019 \\
\hline Lansia Awal & 1 & 14,3 & 6 & 85,7 & 7 & 100,0 & \\
\hline Total & 23 & 23,0 & 38 & 38,0 & 61 & 100,0 & \\
\hline
\end{tabular}

\section{PEMBAHASAN}

Berdasarkan pengolahan data maka dapat diketahui bahwa usia pada pasien systemic lupus erythematosus (SLE) di Komunitas Odapus Lampung (KOL) Tahun 2019 sebagian besar dengan kategori usia 26-35 tahun (dewasa awal) sebanyak 20 responden $(32,8 \%)$, kategori usia 36-45 tahun (dewasa akhir) sebanyak 19 responden $(31,1 \%)$, kategori usia 17-25 tahun (remaja akhir) sebanyak 15 responden $(24,6 \%)$, kategori usia 46-55 tahun (lansia awal) sebanyak 7 responden $(11,5 \%)$.

Penyakit systemic lupus erythematosus (SLE) ialah auto imun kronis yang sampai saat ini belum diketahui secara pasti penyebabnya, biasanya perempuan produktif dengan usia (15-44 tahun) sangat rentan terkena SLE namun juga bisa menyerang laki-laki, kelompok anak serta remaja. Menurut Joewono Soeroso, dokter pakar rematologi RSUD Dr. Soetomo Surabaya menyatakan bahwa produksi hormon estrogen yang berlebihan pada wanita akan mempengaruhi sel-sel kekebalan tubuh sehingga sel-sel kekebalan tubuh bertindak super aktif menyerang "benda asing" seperti virus dan kuman juga sel-sel tubuh sendiri. Wanita sendiri akan terus memproduksi hormon estrogen sampai ia menopause. Hal ini menyebabkan kemungkinan terkena Lupus juga lebih besar (Nadhiroh, 2007).

Peningkatan hormon dalam tubuh dapat memicu terjadinya SLE. 
Beberapa studi menemukan korelasi antara peningkatan resiko lupus dan tingkat estrogen yang tinggi. Studi lain juga menunjukkan bahwa metabolisme estrogen yang abnormal dapat dipertimbangkan sebagai faktor resiko terjadinya SLE (Tahitian, 2013).

Penyakit SLE merupakan penyakit inflamasi autoimun kronik, dengan etiologi yang belum diketahui. Manifestasi klinis, perjalanan penyakit dan prognosis penyakit SLE sangat beragam. Sistem kekebalan tubuh pada penyakit ini akan mengalami kehilangan kemampuan untuk melihat perbedaan antara substansi asing dengan sel dan jaringan tubuh sendiri. Pada penyakit SLE terjadi produksi antibodi yang berlebihan namun tidak menyerang kuman atau antigen akan tetapi menyerang sistem kekebalan sel dan jaringan tubuh sendiri. Antibodi seperti ini disebut "auto-antibodi" yang bereaksi dengan antigen "self" membentuk kompleks imun. Kompleks imun yang menempel dalam jaringan akan mengakibatkan terjadinya peradangan dan kerusakan pada jaringan (Kemenkes RI,2016).

$\mathrm{Hal}$ ini sesuai dengan teori yang menyatakan bahwa penyakit systemic lupus erythematosus (SLE) bisa menyerang siapa saja akan tetapi sebagian besar yang terkena perempuan produktif dengan usia (1544 tahun). (Kemenkes RI,2017). Belum diketahui secara pasti penyebab penyakit systemic lupus erythematosus (SLE), ada beberapa faktor yang diduga akan menjadi faktor resiko penyakit tersebut yaitu regulasi sistem imun, hormon, genetik, lingkungan dan epigenetik. Orang yang telah terdiagnosa mengalami penyakit lupus akan mengeluh kelelahan, berat badan turun, demam, anoreksia, malaise, gejala klinisnya akan lebih spesifik, lengkap dan akan cenderung melibatkan sistem organ lainnya jika penderita yang telah lanjut.

Dari hasil analisis data penelitian diketahui bahwa usia pada pasien systemic lupus erythematosus (SLE) di Komunitas Odapus Lampung (KOL)
Tahun 2019 sebagian besar perempuan produktif dengan usia 17-54 tahun, sesuai teori yang menyatakan kemungkinan besar yang sering terkena penyakit lupus yaitu perempuan produktif, hormon estrogen yang berlebihan pada wanita akan mempengaruhi sel-sel kekebalan tubuh sehingga sel-sel kekebalan tubuh bertindak super aktif menyerang "benda asing" seperti virus dan kuman juga sel-sel tubuh sendiri. Wanita sendiri akan terus memproduksi hormon estrogen sampai ia menopause.

Kelelahan merupakan penyebab utama morbiditas pada penderita SLE, serta penurunan kualitas hidup dan tingkat keparahan SLE dengan kriteria ringan sampai berat (Perhimpunan Reumatologi Indonesia,2011). Pada penderita SLE kelelahan ialah hal yang biasa yang sangat sering dirasakan. $53-80 \%$ penelitian menunjukan penderita SLE mengalami kelelahan sebagai suatu gejala utama mereka, pada $30-50 \%$ penderita SLE kelelahan adalah suatu gejala yang mengganggu fungsi fisik, social dan emosional serta yang paling melemahkan (Alvina 2007). Kelelahan merupakan faktor pencetus kekambuhan selain sinar matahari dan merupakan salah satu pencetus kondisi yang memperburuk gejala SLE. Pada penderita SLE system pertahanan tubuh melawan infeksi yang dihasilkan antibodi menyerang tubuhnya sendiri, pada keadaan orang normal sistem kekebalan tubuh akan berfungsi dengan semestinya untuk melindungi dan mengendalikam pertahanan tubuh melawan infeksi. Kelelahan merupakan keluhan yang umum dijumpai pada penderita SLE dan biasanya mendahului berbagai manifestasi klinis lainnya.

Semakin bertambahnya umur akan semakin rentan terjadinya kelelahan. Penuaan akan mengakibatkan kerusakan secara bertahap pada sistem fisiologis. Kebanyakan kinerja fisik mencapai puncak dalam usia pertengahan dua puluhan dan kemudian menurun 
dengan bertambahnya usia (David, 1996). Departemen Kesehatan RI menyebutkan bahwa usia produktif adalah antara 15-54 tahun.

Berdasarkan hasil penelitian yang dilakukan di Komunitas Odapus Lampung sesuai dengan teori bahwa ada hubungan antara usia dengan kelelahan. Penderita lupus cenderung mengalami kelalahan dan menganggap bahwa kelelahan merupakan gejala awal dari penyakit tersebut, kelelahan yang mereka rasakan sangat mengganggu fungsi fisik, social, emosional serta yang paling melemahkan, kelelahan juga menyebabkan mereka sulit berkonsentrasi dan beraktivitas.

\section{KESIMPULAN}

1. Distribusi frekuensi usia pada pasien systemic lupus erytematosus (SLE) di Komunitas Odapus Lampung (KOL) di Tahun sebagian besar dengan kategori usia 26-35 tahun (dewasa awal) sebanyak 20 responden $(32,8 \%)$.

2. Gambaran tingkat kelelahan pada pasien Systemic Lupus Erythematosus (SLE) di Komunitas Odapus Lampung (KOL) di Tahun 2019 sebagian besar dengan kategori kelelahan sebanyak 38 responden $(62,3 \%)$.

3. Ada hubungan antara faktor usia dengan kelelahan pada pasien Systemic Lupus Erythematosus (SLE) di Komunitas Odapus Lampung (KOL) Tahun 2019 ( $p$ valeu $0,019<a=0,05)$.

\section{SARAN}

1. Petugas kesehatan

Disarankan untuk dapat meningkatkan perkembangan ilmu pengetahuan khususnya dalam ilmu kedokteran dalam pengobatan pasien lupus dengan lebih ditingkatkan terutama dalam hal kelelahan mengingat sebagian besar gejala awal penderita lupus mudah mengalami kelelahan, serta bagi petugas kesehatan untuk mengedukasi dan mengingatkan pasien dan keluarga pasien untuk mengurangi dan membatasi aktivitas yang bisa menyebabkan kelelahan.

2. Pasien ODAPUS

Disarankan pasien untuk mengurangi dan membatasi aktivitas yang bisa menyebabkan kelelahan dan banyak istirahat, karena kelelahan merupakan gejala yang mengganggu fungsi fisik, social, dan emosional serta yang paling melemahkan. Kelelahan juga merupakan faktor pencetus kekambuhan selain sinar matahari dan merupakan salah satu pencetus kondisi yang memperburuk gejala SLE. Dan pasien juga disarankan agar menambah pengetahuan terkait penyakit yang dialami dengan mencari informasi melalui kegiatan penyuluhan atau seminar yang dilakukan dikomunitas ODAPUS.

3. Bagi Keluarga ODAPUS

Dan disarankan kepada pihak keluarga untuk bisa memberi nasehat serta bisa mengawasi pasien dalam hal aktivitas yang mereka lakukan sehari-hari karena aktivitas yang berlebih juga bisa memicu terjadinya kelelahan.

4. Peneliti lain

Dengan penelitian ini dapat menjadi tambahan informasi dan pengembangan penelitian berikutnya dan untuk melanjutkan penelitian serta meneliti variabel lain yang berbeda.

\section{UCAPAN TERIMAKASIH}

Ucapan terimakasih ini disampaikan kepada Universitas Malahayati yang telah mendukung pelaksanaan penelitian.

\section{DAFTAR PUSTAKA}

Avina, J. A. (2007). The Importance of Fatigue in Lupus. In BC Lupus Society Symposium Arthritis Research Centre of Canada.

Cleanthous, S., Tyagi, M., Isenberg, D.A., \& Newman, S.P. (2012). What do we know about self- 
reported fatigue in systemic lupus erythematosus. Lupus, 21 (5), 465-476.

David, L. (1996). Tubuh Manusia, Jakarta: Arcan.

Djoerban, Z. (2010). Hari Lupus Sedunia. http:/zubairidjoerban.org/harilupus sedunia.

Ferucci, ED., Johnston, JM., Gaddy, JR., Sumner, L., Posever, JO., Choromanski, TL., Gordon, C., Lim, SS., dan Helmick, CG. (2014). Prevalence and Incidence of Systemic Lupus Erythematosus in a PopulationBased Registry of American Indian and Alaska Native People,. http://www.ncbi.nlm.nih.gov/p mc/articles/PMC4617772

Kemenkes RI. (2016). Pedoman Pengendalian Lupus Erythematosus Sistemik (LES). Pencegahan dan Pengendalian Penyakit Tidak Menular. Jakarta : Kemenkes Kesehatan RI.

Kemenkes RI. (2017). Situasi lupus di Indonesia. Pusat data dan informasi. Jakarta : Kemenkes Kesehatan RI

Nadhiroh, F., (2007). Lupus: penyakit seribu wajah dominan menyerang wanita. http://surabaya.detik.com.

Perhimpunan Reumatologi Indonesia.

(2011). Diagnosis dan pengelolaan Lupus Erythematosus Sistemik.

Tahitan, N. (2007). Tahukah anda penyebab penyakit lupus http://penyebablupus.com/ 